\title{
THE ANALYSIS OF COMPARISON RESULTS USING EROSION AND OPENING ON THE PIAS CARD SEGMENTATION PROCESS (CASE STUDY: ST. BARONGAN)
}

\author{
Asih Pujiastuti \\ Program Studi Teknik Informatika \\ Sekolah Tinggi Teknologi Adisutjipto \\ J1. Janti Blok-R Lanud Adisutjipto Yogyakarta \\ asihpuji@stta.ac.id
}

\begin{abstract}
This research was conducted to improve the application used in the calculation of the sunshine duration. The research that has been done using the opening method for segmentation of the pias card. The error or failure of segmentation is caused by a small burning object of the pias card and or a thin but translucent object, so that the object is partially lost or forms an object's separation area. Based on the error or failure of segmentation in the above research, the research will be done is to develop similar applications by replacing one of the methods with erosion morphology. The test was carried out with 92 data and the results stated that Erosion with Radius $=3$ became the best alternative method in this research with RMSE 3.14.
\end{abstract}

Keyword: segmentation, object, pias card,opening, erosion.

\begin{abstract}
Abstrak
Penelitan ini dilakukan untuk memperbaiki aplikasi yang digunakan pada perhitungan lama penyinaran matahari. Penelitian yang sudah dilakukan menggunakan metode opening untuk segmentasi kartu pias. Kesalahan atau kegagalan segmentasi disebabkan oleh objek kecil yang terbakar kartu pias dan atau benda tipis tetapi tembus cahaya, sehingga objek tersebut hilang sebagian atau membentuk area pemisahan objek. Berdasarkan kesalahan atau kegagalan segmentasi dalam penelitian di atas, maka penelitian yang akan dilakukan adalah mengembangkan aplikasi serupa dengan mengganti salah satu metode dengan erosi morphologi. Pengujian dilakukan dengan 92 data dan hasilnya menyatakan bahwa Erosi dengan Radius $=3$ menjadi metode alternatif terbaik dalam penelitian ini dengan RMSE 3.14. Kata Kuci : segmentasi, objek, kartu pias, opening, erosi.
\end{abstract}

\section{Pengantar}

Perhitungan hasil pengukuran lama penyinaran matahari oleh operator stasiun klimatologi dengan menggunakan alat Campbell Stokes dan kartu pias. Perhitungan hasil pengukuran memerlukan ketelitian dan konsitensi penilaian terhadap objek pembakaran yang terekam pada kertas pias. Penentuan objek bekas bakar yang valid menentukan keakuratan hasil perhitungan. Penelitian dengan judul "Segmentasi Citra Kartu Pias Tipe SO-40U (1400-40S) Pada Perhitungan Lama Penyinaran Matahari ”, adalah merancang dan membangun software aplikasi untuk segmentasi bekas bakar pada kartu pias secara otomatis [5]. Pengujian aplikasi dilakukan dengan membandingkan jumlah objek hasil segmentasi aplikasi dengan jumlah objek perhitungan manual fisik pada kartu pias. Kesimpulan yang didapatkan salah satunya adalah terdapat selisih hasil perhitungan objek antara perhitungan aplikasi dengan perhitungan manual. Selesih yang terjadi disebabkan oleh kesalahan segmentasi pada beberapa pengujian. Kesalahan atau kegagalan segmentasi disebabkan oleh objek bekas bakar kartu pias yang kecil dan atau objek tembus namun tipis, sehingga objek sebagian hilang atau membentuk area pemisah objek. 
Berdasarkan kesalahan atau kegagalan segmentasi pada penelitian tersebut diatas, maka penelitian yang akan dilakukan adalah mengembangkan aplikasi serupa dengan menggantikan salah satu metode segmentasi yang sudah dilakukan. Pada penelitian [5], salah satu metode segmentasi menggunakan operasi Opening. Pada penelitian yang diusulkan akan menggantikan operasi morphologi Opening dengan operasi morphologi Erosi. Erosi merupakan operasi morphologi yang dengan mengurangi pixel pada batas antar objek dalam suatu citra digital, sedangkan Opening merupakan kombinasi proses pengurangan pixel pada batas antar objek dalam suatu citra digital yang dilanjutkan dengan penambahan pixel pada batas antar objek. Harapan penggantian metode ini bertujuan untuk mempertahankan bekas bakar kartu pias yang tipis dan memanjang, sehingga objek tersebut tidak hilang.

\section{Metodologi Penelitian}

Data penelitian berjumlah 92 dan diperoleh dari St. Barongan data terdiri dari tiga tipe kartu pias yaitu; SO-40U (1400-40S), SO-40W (1400-40W), dan Tipe SO-40F (1400-40F). Akuisisi citra kartu pias dilakukan dengan cara yang sama seperti pada penelitian sebelumnya yaitu dengan memindai kartu pias menggunakan scanner[1],[3],[4], dan [7]. Skenario pengujian sistem aplikasi segmentasi kartu pias dilakukan dengan mekanisme langkahlangkah sebagai berikut;

1. Memilih file kartu pias sebagai input sistem,

2. Menentukan proses segmentasi dengan Erosi atau Opening,

3. Mengatur nilai Radius, nilai Radius dimulai dari Radius $=1$ kemudian diproses dan didapatkan hasilnya,

4. Proses diulangi dengan meningkatkan nilai Radius sampai didapatkan output bebas dari noise.

5. Perhitungan Analisa hasil menggunakan RMSE dengan uraian sebagai berikut;

$$
R M S E=\sqrt{\sum \frac{\left(z-z^{\prime}\right)^{2}}{n}}
$$

dengan:

$$
\begin{array}{ll}
\mathrm{z} & =\text { data perhitungan pengamat (manual), } \\
z^{\prime}{ }_{i} & =\text { data perhitungan sistem (Erosi ataupun Opening), } \\
\mathrm{n} & =\text { jumlah data. }
\end{array}
$$

\subsection{Prinsip Kerja Sistem}

Penelitian yang dilakukan digambarkan melalui flowchart yang dapat dilihat pada gambar 2. Flowchart sistem merupakan gambaran prosedur yang menjadi acauan dalam berjalannya sebuah sistem. Prosedur berjalannya sistem dapat dijelaskan dengan tahapan berikut:

1. Sistem dimulai dengan input citra kartu,

2. Sistem melakukan proses greyscale, untuk mendapatkan citra keabuan,

3. Output dari grayscale kemudian dilakukan proses Threshold untuk mendapatkan citra biner, kemudian di-complement-kan, pada penelitian ini metode Theshold dilakukan dengan metode otsu [2] dan [6],

4. Setelah citra menjadi citra biner kemudian dilakukan operasi morphologi Opening, atau operasi morphologi Erosi,

5. Componen conecting labelling bertujuan untuk pengelompokan pixel untuk membentuk objek,

6. Noise removing dilakukan untuk menghilangkan objek yang dikelompokan sebagai noise,

7. Setelah selesai pengilangan noise kemudian dilakukan proses penghitungan objek,

8. Output dari sistem ini adalah citra objek dan jumlah objek, selesai. 
Perancangan alir data pada sistem digambakan dengan diagram kontek yang dapat dilihat pada Gambar 1. Eksternal entiti pada sistem adalah User. Diagram konteks menjelaskan bahwa ada alir data secara umum, yaitu menggambarkan aliran data input dari user dan aliran data sebagai output sistem.

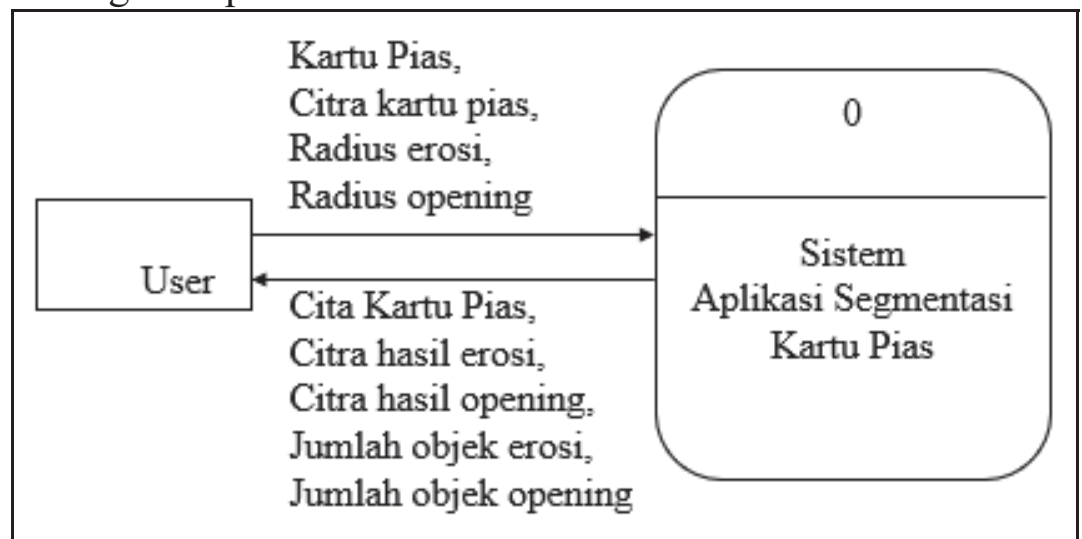

Gambar 1 Diagram Konteks Sistem Aplikasi segmentasi citra kartu pias

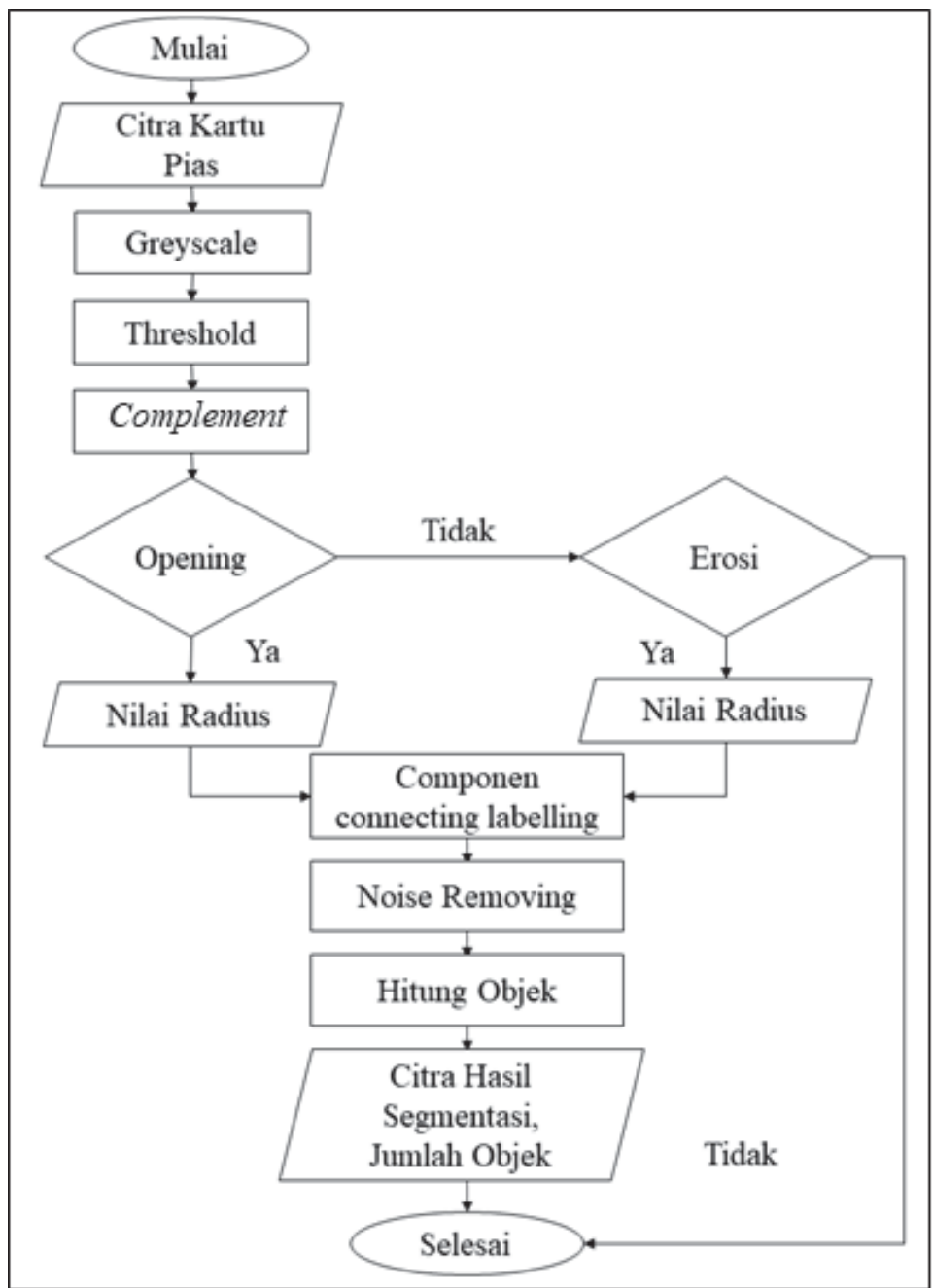

Gambar 2. Flowchart Aplikasi Segmentasi Citra Kartu Pias

\section{Hasil dan Pembahasan}

Pengujian dilakukan dengan pengolahan 92 citra kartu pias dengan tiga tipe kertas pias yang berbeda. hasil pengujian sistem yang dilakukan dapat dilihat pada tabel 1 , tabel 2 , dan 
tabel 3. Analisa dari hasil pengujian dihitung menggunakan RMSE dan berikut kesimpulan hasil setiap tabel

1) Pada tabel 1. Perhitungan RMSE Hasil Pengujian Tipe SO-40U (1400-40S) menunjukan bahwa Opening dengan Radius 3 mempunyai RMSE sebesar 4,12.

2) Pada tabel 2. Perhitungan RMSE Hasil Pengujian Tipe SO-40W (1400-40W) menunjukan bahwa Erosi dengan Radius 2 mempunyai RMSE sebesar 3,48.

3) Pada tabel 3. Perhitungan RMSE Hasil Pengujian Tipe SO-40F (1400-40F) menunjukan bahwa Erosi dengan Radius 3 mempunyai RMSE sebesar 3,45.

4) Ditinjau dari tabel 1, 2, dan 3 dapat disimpulkan bahwa secara general Erosi dengan Radius 3 mempunyai rata-rata RMSE 4,57, maka dapat dikatakan Erosi dengan Radius 3 merupakan metode terbaik untuk membantu proses segmentasi citra kartu pias pada penelitian ini.

Berdasarkan pengujian dan Analisa hasil pengujian system pada penelitian ini diperoleh fakta -fakta baru, antara lain sebagai berikut:

1) Erosi dapat mengurangi noise, akan tetapi Erosi pada data kartu pias tetentu justru menambah noise. Hal tersebut disebabkan oleh sifat Erosi yang bekerja dengan memperkecil luasan objek. Karena luasan diperkecil mengakibatkan objek yang seharusnya dianggap noise dan berhubungan dengan noise tepi citra putus, sehinggan noise dianggap objek dan tidak ikut dihilangkan dengan prinsip kerja system yang dapat menghilangkan noise tepian citra. Gambar 3., perhatikan tanda lingkaran merah menjukan terbentuknya objek baru yang dikarenakan Erosi dengan meningkatkan nilai Radius (R).

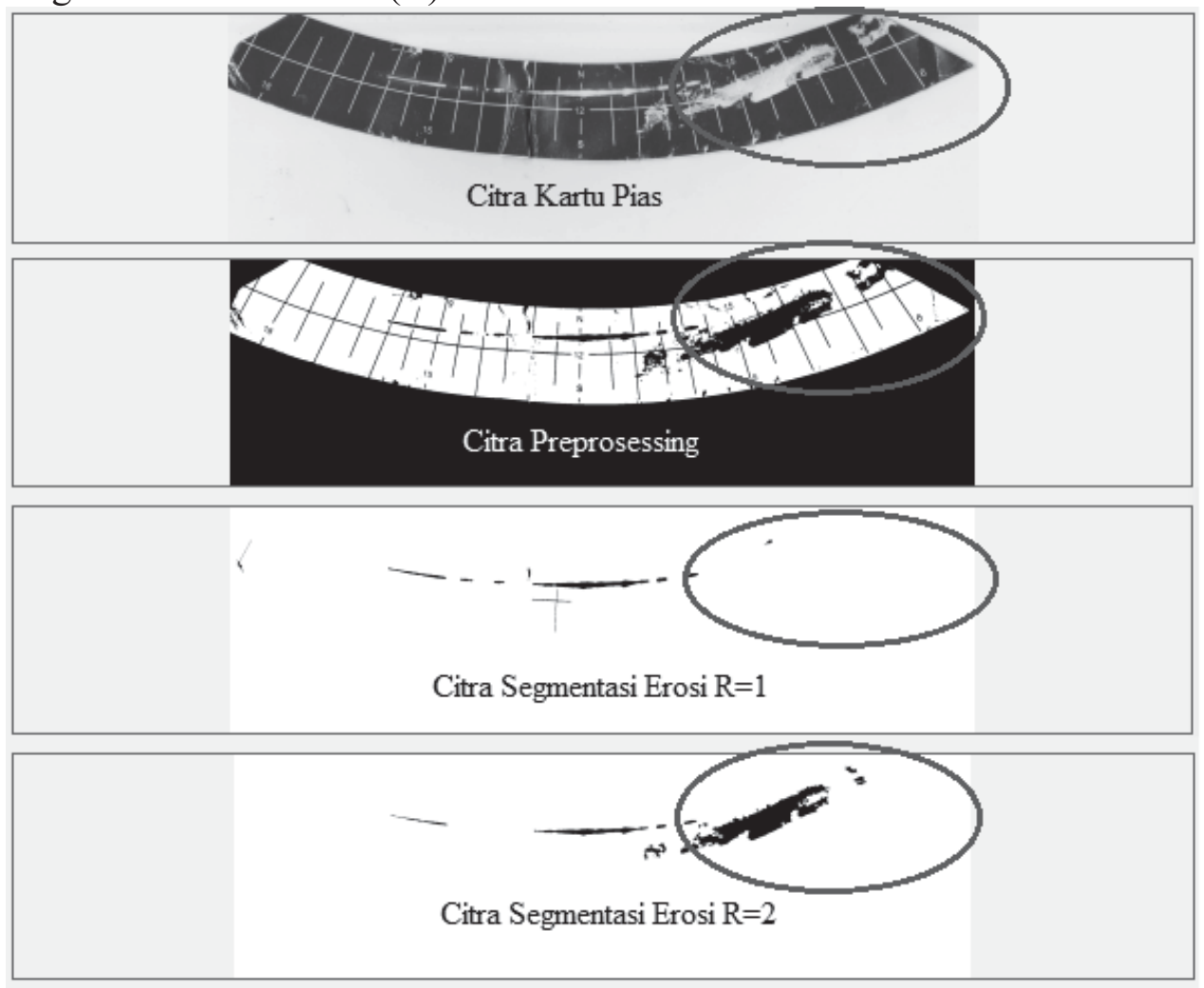

Gambar 3. Kelemahan Erosi

2) Opening menghasilkan luasan objek segmentasi lebih baik jika dibandingkan dengan luasan objek citra data uji dari pada Erosi yang menghasikan luasan objek segmentasi menipis dibandingkan dengan luasan objek citra data uji yang sama, dapat dilihat pada gambar 4 dan 5. Gambar 6 menunjukan kelemahan dari Opening yaitu dapat membentu objek baru yang diakhibatkan objek hasil segmentasi putus. 

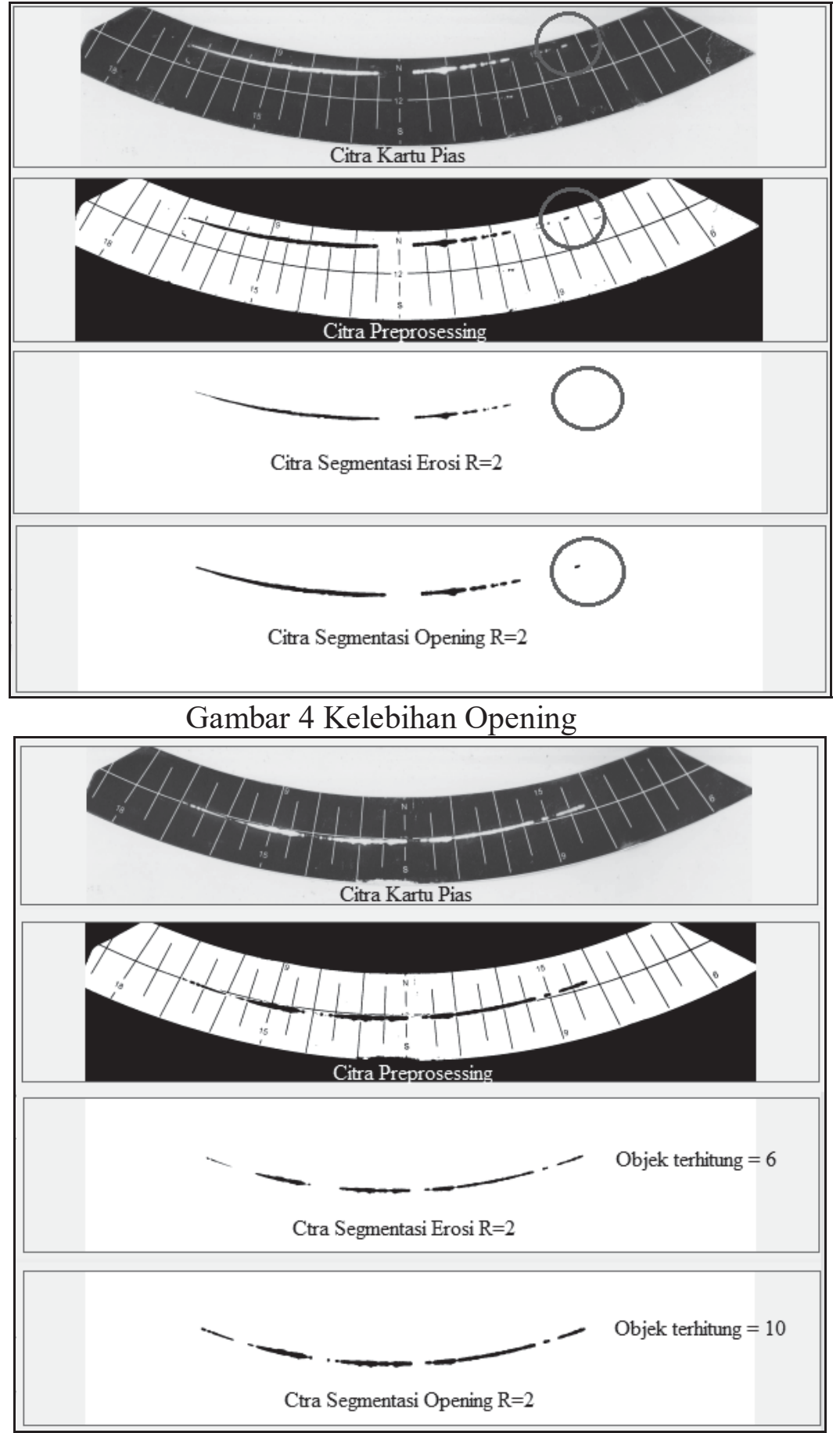

Gambar 5. Opening Membentuk objek baru

Hasil perhitungan RMSE juga dipengaruhi oleh Kondisi cacat bawaan oleh kartu pias yang disebabkan salah satunya adalah faktor cuaca. Terik matahari ataupun hujan dapat menyebabkan kerusakan kartu sehingga menbentuk noise saat proses segmentasi dilakukan. Kartu pias dengan kondisi cacat dapat dilihat pada gambar 


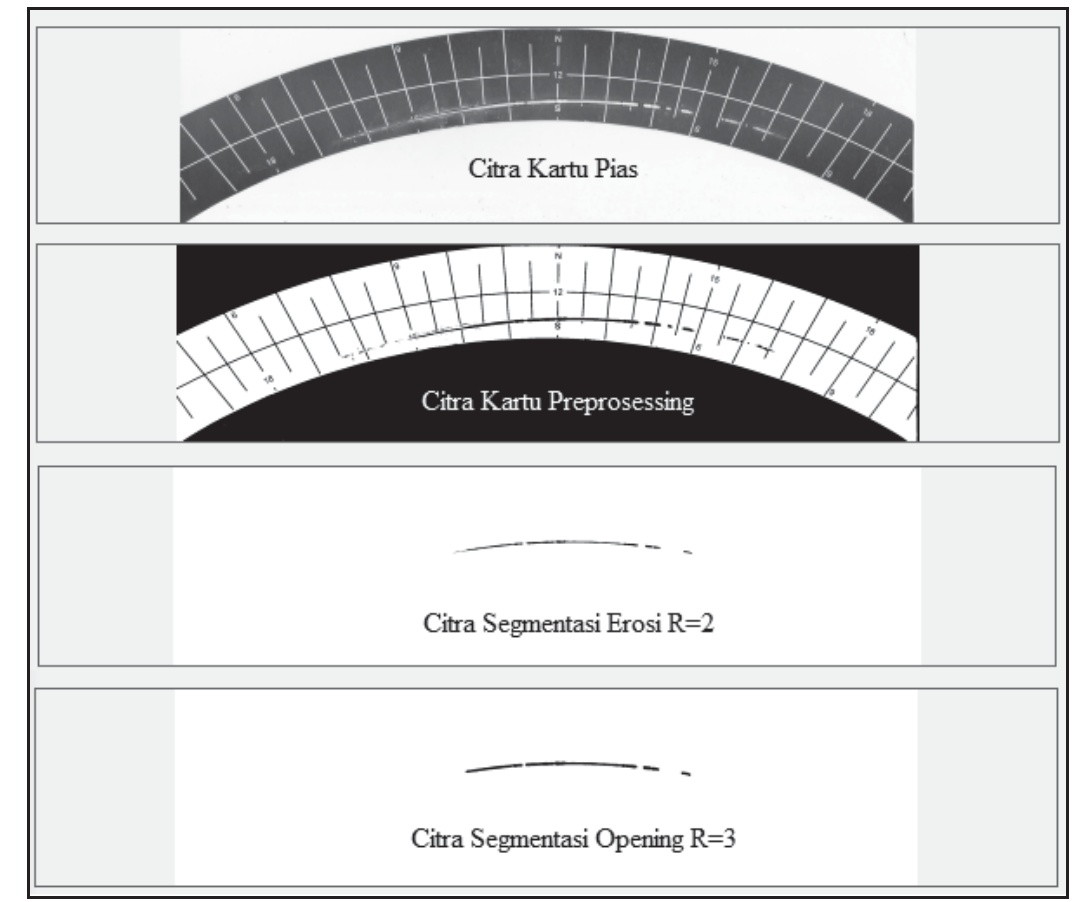

Gambar 4.6 Objek Citra Erosi Lebih Tipis Dibandingkan Opening

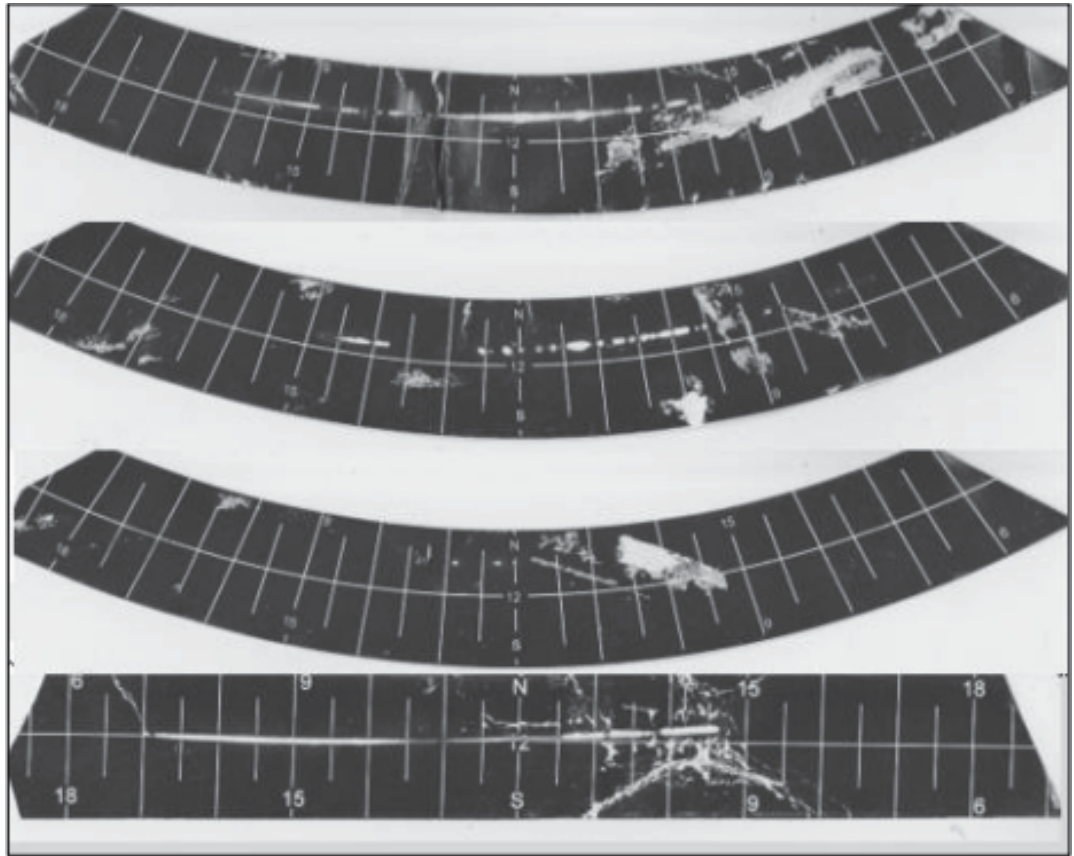

Gambar 4.7 Kartu Pias dengan cacat bawaan

Tabel 1. Perhitungan RMSE Hasil Pengujian Tipe SO-40U (1400-40S)

\begin{tabular}{|l|l|l|c|c|c|c|c|}
\hline \multirow{3}{*}{ No. } & \multirow{3}{*}{ Nama File } & \multicolumn{5}{|c|}{$\frac{\left(z-z^{\prime}\right)^{2}}{n}$} \\
\cline { 3 - 8 } & & \multicolumn{3}{|c|}{ Erosi } & \multicolumn{3}{c|}{ Opening } \\
\cline { 3 - 8 } & & $\mathbf{R}=\mathbf{1}$ & $\mathbf{R}=\mathbf{2}$ & $\mathbf{R}=\mathbf{3}$ & $\mathbf{R}=\mathbf{1}$ & $\mathbf{R}=\mathbf{2}$ & $\mathbf{R}=\mathbf{3}$ \\
\hline 1 & 1-6-2017.jpg & 0.00 & 0.83 & 0.83 & 1.20 & 0.03 & 0.13 \\
\hline 2 & 10-6-2017.jpg & 0.53 & 0.00 & 0.13 & 4.03 & 0.83 & 0.53 \\
\hline 3 & 11-6-2017.jpg & 0.83 & 0.03 & 0.30 & 4.03 & 1.63 & 0.03 \\
\hline
\end{tabular}




\begin{tabular}{|c|c|c|c|c|c|c|c|}
\hline \multirow{3}{*}{ No. } & \multirow{3}{*}{ Nama File } & \multicolumn{6}{|c|}{$\left(z-z^{\prime}\right)^{2}$} \\
\hline & & \multicolumn{3}{|c|}{ Erosi } & \multirow[b]{2}{*}{$R=1$} & \multirow[b]{2}{*}{$R=2$} & \multirow[b]{2}{*}{$\mathbf{R}=\mathbf{3}$} \\
\hline & & $\mathbf{R}=\mathbf{1}$ & $\mathbf{R}=\mathbf{2}$ & $\mathbf{R}=\mathbf{3}$ & & & \\
\hline 4 & 12-6-2017.jpg & 0.13 & 0.00 & 0.00 & 3.33 & 0.13 & 0.00 \\
\hline 5 & 13-6-2017.jpg & 0.30 & 3.33 & 4.03 & 4.80 & 0.13 & 2.13 \\
\hline 6 & 14-6-2017.jpg & 0.83 & 3.33 & 4.03 & 0.03 & 0.03 & 1.20 \\
\hline 7 & 15-6-2017.jpg & 0.30 & 0.00 & 0.00 & 2.13 & 0.13 & 0.00 \\
\hline 8 & 16-6-2017.jpg & 0.83 & 0.00 & 0.03 & 3.33 & 0.13 & 0.13 \\
\hline 9 & 17-6-2017.jpg & 0.83 & 0.13 & 0.00 & 3.33 & 2.13 & 0.53 \\
\hline 10 & 18-6-2017.jpg & 0.30 & 0.13 & 0.13 & 1.63 & 0.30 & 0.53 \\
\hline 11 & 19-6-2017.jpg & 0.03 & 1.20 & 1.63 & 2.70 & 0.00 & 0.03 \\
\hline 12 & 2-6-2017.jpg & 0.13 & 0.13 & 0.13 & 3.33 & 0.03 & 0.03 \\
\hline 13 & 20-6-2017.jpg & 0.13 & 0.30 & 0.30 & 3.33 & 0.30 & 0.03 \\
\hline 14 & 21-6-2017.jpg & 3.33 & 5.63 & 8.53 & 0.30 & 4.03 & 4.80 \\
\hline 15 & 22-6-2017.jpg & 0.13 & 2.13 & 4.03 & 0.83 & 0.53 & 1.20 \\
\hline 16 & 23-6-2017.jpg & 1.20 & 0.03 & 0.53 & 5.63 & 2.70 & 0.53 \\
\hline 17 & 24-6-2017.jpg & 0.00 & 0.13 & 0.53 & 2.13 & 0.13 & 0.00 \\
\hline 18 & 25-6-2017.jpg & 0.13 & 0.03 & 0.13 & 1.63 & 1.20 & 0.30 \\
\hline 19 & 26-6-2017.jpg & 0.03 & 2.13 & 2.70 & 4.80 & 0.30 & 0.30 \\
\hline 20 & 27-6-2017.jpg & 0.00 & 1.20 & 2.70 & 3.33 & 0.00 & 0.30 \\
\hline 21 & 28-6-2017.jpg & 1.20 & 0.00 & 0.13 & 5.63 & 0.13 & 1.63 \\
\hline 22 & 29-6-2017.jpg & 2.70 & 0.30 & 0.00 & 10.80 & 1.63 & 0.30 \\
\hline 23 & 3-6-2017.jpg & 0.30 & 0.30 & 0.13 & 2.13 & 0.30 & 0.03 \\
\hline 24 & 30-6-2017.jpg & 1.20 & 0.00 & 0.00 & 7.50 & 0.00 & 0.30 \\
\hline 25 & 4-6-2017.jpg & 0.30 & 0.53 & 1.20 & 0.53 & 0.03 & 0.13 \\
\hline 26 & 5-6-2017.jpg & 0.13 & 0.13 & 0.30 & 7.50 & 0.30 & 0.13 \\
\hline 27 & 6-6-217.jpg & 1.63 & 0.00 & 0.03 & 9.63 & 0.53 & 0.30 \\
\hline 28 & 7-6-2017.jpg & 0.03 & 1.20 & 1.20 & 2.70 & 0.00 & 0.03 \\
\hline 29 & 8-6-2017.jpg & 1.20 & 0.53 & 0.53 & 4.80 & 0.53 & 0.13 \\
\hline 30 & 9-6-2017.jpg & 0.30 & 0.03 & 0.53 & 4.80 & 0.53 & 1.20 \\
\hline & $\sum \frac{\left(z-z^{\prime}\right)^{2}}{n}$ & 19.03 & 23.77 & 34.80 & 111.93 & 18.73 & 16.97 \\
\hline & $\sqrt{\sum \frac{(z-z}{n}}$ & 4.36 & 4.88 & 5.90 & 10.58 & 4.33 & 4.12 \\
\hline
\end{tabular}


Tabel 2. Perhitungan RMSE Hasil Pengujian Tipe SO-40W (1400-40W)

\begin{tabular}{|c|c|c|c|c|c|c|c|}
\hline \multirow{3}{*}{ No. } & \multirow{3}{*}{ Nama File } & \multicolumn{6}{|c|}{$\frac{\left(z-z^{\prime}\right)^{2}}{n}$} \\
\hline & & \multicolumn{3}{|c|}{ Erosi } & \multicolumn{3}{|c|}{ Opening } \\
\hline & & $\mathrm{R}=\mathbf{1}$ & $R=2$ & $\mathbf{R}=\mathbf{3}$ & $R=1$ & $\mathrm{R}=\mathbf{2}$ & $\mathbf{R}=\mathbf{3}$ \\
\hline 1 & 1-1-2018.png & 0.13 & 0.29 & 1.16 & 0.03 & 0.13 & 0.13 \\
\hline 2 & 10-1-2018.png & 0.03 & 0.03 & 0.03 & 0.52 & 0.13 & 0.52 \\
\hline 3 & 11-1-2018.png & 0.52 & 1.58 & 2.61 & 0.03 & 0.29 & 0.52 \\
\hline 4 & 12-1-2018.png & 0.03 & 0.00 & 0.00 & 0.81 & 0.03 & 0.13 \\
\hline 5 & 13-1-2018.png & 0.03 & 0.13 & 0.13 & 0.03 & 0.13 & 0.13 \\
\hline 6 & 14-1-2018.png & 0.00 & 0.13 & 0.29 & 0.00 & 0.13 & 0.13 \\
\hline 7 & 15-1-2018.png & 0.29 & 0.52 & 0.81 & 0.00 & 0.29 & 0.29 \\
\hline 8 & 16-1-2018.png & 0.03 & 0.29 & 0.03 & 2.06 & 2.61 & 0.81 \\
\hline 9 & 17-1-2018.png & 2.61 & 0.00 & 0.00 & 2.61 & 0.52 & 1.16 \\
\hline 10 & 18-1-2018.png & 0.52 & 1.16 & 1.16 & 0.03 & 0.29 & 0.03 \\
\hline 11 & 19-1-2018.png & 0.03 & 0.13 & 0.13 & 1.16 & 0.29 & 0.03 \\
\hline 12 & 2-1-2018.png & 0.00 & 0.13 & 0.29 & 0.29 & 0.00 & 0.03 \\
\hline 13 & 20-1-2018.png & 0.52 & 0.29 & 0.00 & 0.81 & 0.81 & 0.81 \\
\hline 14 & 21-1-2018.png & 0.03 & 0.00 & 0.00 & 0.52 & 0.00 & 0.00 \\
\hline 15 & 22-1-2018.png & 0.03 & 0.13 & 0.29 & 1.58 & 0.52 & 0.13 \\
\hline 16 & 23-1-2018.png & 0.13 & 0.03 & 0.03 & 1.16 & 0.03 & 0.00 \\
\hline 17 & 24-1-2018.png & 0.29 & 0.29 & 0.03 & 5.45 & 6.32 & 3.23 \\
\hline 18 & 25-1-2018.png & 0.29 & 0.13 & 0.03 & 6.32 & 2.06 & 2.06 \\
\hline 19 & 26-1-2018.png & 0.03 & 0.13 & 0.29 & 1.16 & 0.03 & 0.00 \\
\hline 20 & 27-1-2018.png & 0.13 & 0.13 & 0.29 & 6.32 & 0.13 & 0.03 \\
\hline 21 & 28-1-2018.png & 0.13 & 0.03 & 0.13 & 2.61 & 0.03 & 0.00 \\
\hline 22 & 29-1-2018.png & 0.00 & 0.00 & 0.13 & 6.32 & 12.90 & 8.26 \\
\hline 23 & 3-1-2018.png & 0.00 & 0.13 & 0.29 & 1.16 & 0.00 & 0.00 \\
\hline 24 & 30-1-2018.png & 3.23 & 1.16 & 0.13 & 7.26 & 1.58 & 1.58 \\
\hline 25 & 31-1-2018.png & 7.26 & 0.13 & 0.52 & 21.81 & 0.13 & 0.29 \\
\hline 26 & 4-1-2018.png & 0.52 & 0.81 & 0.81 & 0.13 & 0.13 & 0.13 \\
\hline 27 & 5-1-2018.png & 0.29 & 0.52 & 0.52 & 0.03 & 0.13 & 0.13 \\
\hline 28 & 6-1-2018.png & 0.52 & 0.81 & 2.06 & 0.00 & 0.29 & 0.03 \\
\hline 29 & 7-1-2018.png & 0.52 & 1.16 & 2.61 & 0.00 & 0.03 & 0.13 \\
\hline 30 & 8-1-2018.png & 0.81 & 1.58 & 1.58 & 0.81 & 0.03 & 0.13 \\
\hline 31 & 9-1-2018.png & 0.29 & 0.29 & 0.13 & 2.06 & 0.52 & 0.81 \\
\hline & $\sum \frac{\left(z-z^{\prime}\right)^{2}}{n}$ & 19.23 & 12.13 & 16.52 & 73.10 & 30.52 & 21.65 \\
\hline & $=\sqrt{\sum \frac{\left(z-z^{2}\right)^{2}}{n}}$ & 4.38 & 3.48 & 4.06 & 8.55 & 5.52 & 4.65 \\
\hline
\end{tabular}


Tabel 3. Perhitungan RMSE Hasil Pengujian Tipe SO-40F (1400-40F)

\begin{tabular}{|c|c|c|c|c|c|c|c|}
\hline \multirow{3}{*}{ NO } & \multirow{3}{*}{ Nama File } & \multicolumn{6}{|c|}{$\frac{\left(z-z^{\prime}\right)^{2}}{n}$} \\
\hline & & \multicolumn{3}{|c|}{ Erosi } & \multicolumn{3}{|c|}{ Opening } \\
\hline & & $\mathrm{R}=1$ & $\mathbf{R}=\mathbf{2}$ & $\mathbf{R}=\mathbf{3}$ & $\mathrm{R}=\mathbf{1}$ & $\mathbf{R}=\mathbf{2}$ & $\mathbf{R}=\mathbf{3}$ \\
\hline 1 & 1-3-2018.png & 7.26 & 0.13 & 0.52 & 15.61 & 9.32 & 0.81 \\
\hline 2 & 10-3-2018.png & 23.52 & 1.16 & 0.03 & 33.03 & 8.26 & 1.16 \\
\hline 3 & 11-3-2018.png & 14.23 & 0.03 & 0.00 & 21.81 & 8.26 & 0.81 \\
\hline 4 & 12-3-2018.png & 14.23 & 0.00 & 0.03 & 31.00 & 6.32 & 0.13 \\
\hline 5 & 13-3-2018.png & 20.16 & 0.03 & 0.81 & 23.52 & 12.90 & 0.81 \\
\hline 6 & 14-3-2018.png & 29.03 & 0.81 & 0.03 & 33.03 & 18.58 & 3.90 \\
\hline 7 & 15-3-2018.png & 29.03 & 1.58 & 0.00 & 37.29 & 7.26 & 2.06 \\
\hline 8 & 16-3-2018.png & 20.16 & 0.29 & 0.00 & 21.81 & 10.45 & 1.16 \\
\hline 9 & 17-3-2018.png & 11.65 & 0.81 & 0.29 & 14.23 & 21.81 & 2.61 \\
\hline 10 & 18-3-2018.png & 14.23 & 0.52 & 0.00 & 18.58 & 18.58 & 0.81 \\
\hline 11 & 19-3-2018.png & 37.29 & 3.23 & 0.81 & 51.61 & 35.13 & 11.65 \\
\hline 12 & 2-3-2018.png & 5.45 & 0.03 & 0.03 & 11.65 & 6.32 & 0.13 \\
\hline 13 & 20-3-2018.png & 9.32 & 0.03 & 0.81 & 20.16 & 12.90 & 0.29 \\
\hline 14 & 21-3-2018.png & 11.65 & 0.52 & 0.13 & 12.90 & 8.26 & 0.81 \\
\hline 15 & 22-3-2018.png & 10.45 & 1.16 & 0.00 & 14.23 & 14.23 & 1.58 \\
\hline 16 & 23-3-2018.png & 17.06 & 0.52 & 0.00 & 25.29 & 10.45 & 0.81 \\
\hline 17 & 24-3-2018.png & 10.45 & 1.58 & 0.03 & 17.06 & 23.52 & 2.61 \\
\hline 18 & 25-3-2018.png & 11.65 & 0.29 & 0.03 & 10.45 & 7.26 & 0.29 \\
\hline 19 & 26-3-2018.png & 11.65 & 0.52 & 0.03 & 20.16 & 12.90 & 1.58 \\
\hline 20 & 27-3-2018.png & 15.61 & 1.16 & 0.13 & 20.16 & 17.06 & 3.23 \\
\hline 21 & 28-3-2018.png & 15.61 & 1.16 & 0.03 & 23.52 & 27.13 & 2.61 \\
\hline 22 & 29-3-2018.png & 18.58 & 1.58 & 0.03 & 21.81 & 11.65 & 1.16 \\
\hline 23 & 3-3-2018.png & 3.90 & 0.13 & 1.16 & 10.45 & 10.45 & 0.52 \\
\hline 24 & 30-3-2018.png & 14.23 & 0.81 & 0.03 & 17.06 & 7.26 & 2.61 \\
\hline 25 & 31-3-2018.png & 12.90 & 0.52 & 0.00 & 14.23 & 17.06 & 0.81 \\
\hline 26 & 4-3-2018.png & 6.32 & 0.13 & 2.06 & 11.65 & 6.32 & 0.52 \\
\hline 27 & 5-3-2018.png & 8.26 & 0.52 & 0.81 & 11.65 & 10.45 & 0.81 \\
\hline 28 & 6-3-2018.png & 11.65 & 0.13 & 0.13 & 17.06 & 6.32 & 0.13 \\
\hline 29 & 7-3-2018.png & 20.16 & 1.16 & 0.00 & 23.52 & 14.23 & 2.61 \\
\hline 30 & 8-3-2018.png & 62.45 & 15.61 & 3.90 & 56.90 & 65.32 & 56.90 \\
\hline 31 & 9-3-2018.png & 23.52 & 0.81 & 0.00 & 33.03 & 18.58 & 0.52 \\
\hline & $\sum \frac{\left(z-z^{\prime}\right)^{2}}{n}$ & 521.65 & 36.94 & 11.87 & 694.45 & 464.55 & 106.42 \\
\hline & $=\sqrt{\sum \frac{\left(z-z^{\prime}\right)^{2}}{n}}$ & 22.84 & 6.08 & 3.45 & 26.35 & 21.55 & 10.32 \\
\hline
\end{tabular}




\section{Kesimpulan dan Saran}

\subsection{Kesimpulan}

Berdasarkan pengujian yang dilakukan, maka dapat disimpulkan bahwa:

1. Pengujian dilakukan dengan 92 data, hasil pengujian menyatakan Erosi Radius 3 menjadi alternative terbaik pada penelitian ini sebagai metode pembantu segmentasi citra kartu pias dengan RMSE 3,14.

2. Tipe kartu pias berpengaruh pada pemilihan metode pembantu segmentasi, karena setiap tipe mempunyai bekas bakar kartu yang berbeda karakteristiknya.

3. Opening mempunyai kelebihan yaitu dapat mempertahankan luasan objek hasil segmentasi, tetapi pada citra kartu tertentu justru membentuk objek baru yang diakibatkan oleh terputusnya citra objek kartu pias.

4. Erosi cukup baik dalam membantu segmentasi citra kartu pias meskipun menjadikan objek hasil segmentasi menjadi tipis.

5. Kerusakan atau cacat bawaan kartu pias dapat menyebabkan noise tak beraturan.

\subsection{Saran}

Penelitian ini dapat dikembangkan dengan mempertimbangkan saran-saran sebagai berikut:

1. Melakukan penelitian lebih lanjut tentang pengaruh penggabungan Erosi dan Opening untuk membantu proses segmentasi kartu pias.

2. Membuat parameter baru yang adaptif terhadap noise yang terbentuk baik dari pengaruh kerusakan kartu ataupun tipe kartu.

3. Pengukuran ketepatan segmentasi perlu ditambahkan dengan mengukur luasan citra objek hasil segmentasi.

\section{Penutup dan Ucapan Terimakasih}

Besar harapan peneliti bahwa dengan adanya penelitian lanjutan, maka aplikasi terus berkembang dan dapat meninggkat kualitas outputnya. Sehingga dapat dimanfaatkan secara nyata untuk membantu pekerjaan operator stasiun klimatologi dan informasi yang dihasilkan teruji valid. Peneliti menyadari bahwa penelitian yang dilakukan ini masih jauh dari sempurna. Untuk perbaikan ke depan maka peneliti menerima saran maupun kritik yang bersifat membangun. Peneliti mengucapkan terimakasih kepada Kopertis V DIY atas pendanaan pada penelitian ini, yang disalurkan melalui program hibah DIPA KOPERTIS V DIY Tahun Anggaran 2018 No:01 /K.2.2/Dik-P3M/VII/2018 dan St. Barongan yang menyediakan data pengujian.

\section{Daftar Pustaka}

[1]. Fan, Q., \& Zhang, Y. (2013, October). A scorch extraction method for the CampbellStokes sunshine recorder based on multivariable thresholding. In Imaging Systems and Techniques (IST), 2013 IEEE International Conference on (pp. 410-414). IEEE.

[2]. Gonzalez, R.C. dan Woods, R.E., 2008, Digital Image processing, Addison- Wesley Publishing Company, USA.

[3]. Horseman, A., Richardson, T., Boardman, T., Tych, W., Timmis, R., \& Mackenzie, R. (2013). Calibrated digital images of Campbell-Stokes recorder card archives for direct solar irradiance studies. Atmospheric Measurement Techniques, 6(5), 1371-1379.

[4]. Pujiastuti, A., \& Harjoko, A. (2016). Sistem Perhitungan Lama Penyinaran Matahari dengan Metode Otsu Threshold (Studi Kasus: St. Klimatologi Barongan). Compiler, 5(2).

[5]. Pujiastuti, A. (2017). Segmentasi Citra Kartu Pias Tipe SO-40U (1400-40S) pada Perhitungan Lama Penyinaran Matahari. Angkasa, 9(2), 9-22.

[6]. Huang, Q., Gao, W., \& Cai, W. (2005). Thresholding technique with adaptive window selection for uneven lighting image. Pattern recognition letters, 26(6), 801-808.

[7]. Sánchez-Romero, A., González, J. A., Calbó, J., \& Sánchez-Lorenzo, A. (2015). Using 
digital image processing to characterize the Campbell-Stokes sunshine recorder and to derive high-temporal resolution direct solar irradiance. Atmospheric Measurement Techniques, 8(1), 183-194. 